\title{
Examining the Effects of Governance Challenges in Ghana's Local Government System: A Case Study of the Mfantseman Municipal Assembly
}

\author{
Dominic Degraft Arthur \\ University for Development Studies, Wa Campus, Wa, Ghana
}

\begin{abstract}
Local government is established by law to provide grassroot developments. However, in Ghana, local government institutions are not performing their responsibilities effectively due to challenges bedevilling them. In this paper, the researcher seeks to examine the challenges militating against the performance of the Mfantseman Municipal Assembly. To achieve this objective, convenience and purposive sampling techniques were used to select 60 respondents for the study. Qualitative methods such as interviews and focus group discussion were used to collect data for the study. In addition, the discussion was also based on documentary analysis. Ineffective level of accountability and coordination, poor management capacity, inadequate finance, and low level of local participation in the local level programmes were identified as the challenges facing the performance of the Mfantseman Municipal Assembly. The paper recommends the following measures to resolve them. These measures include the creation of more awareness among the citizens to improve the level of participation, recruitment of administrative staff with sharp analytical skills, improvement of the internally generated revenue through investments in resources that yield revenue, and improvement of the institutional building that produces the human capital committed to the principles of good governance at the local level.
\end{abstract}

Keywords: local government, decentralization, political boundaries, local governance, political system

Worldwide, local government has been an extension of the central government. Local government derives its legal existence from the state, and in some cases, all of its human and financial resources come from the (Olowu, 1999). According to De Mello and Lago-Peñas (2012), local governance system has opened up new responsibilities for local government to play a critical role by providing basic public goods and services, and also creating a sense of belonging to different social groups. This is because, unlike the centralized system of administration where the officials have been maligned as "faceless bureaucrats" or "never-at-home politicians", local government officials are often friends, colleagues, neighbours, or acquaintances of those they serve. Local governance has also opened up the opportunity for people to have engagement in the policy process, and access to every phase of the policy cycle (problem identification, agenda setting, policy formulation, policy

Corresponding author: Dominic Degraft Arthur, Mphil in Political Science, University of Ghana, Legon, Ph.D. candidate, Department of Culture and Global Studies, Faculty of Humanities, Aalborg University, Denmark, lecturer, Faculty of Integrated Development Studies, University for Development Studies, Wa, Ghana; research fields: institutional dimensions in governance and development with special interest in decentralization, management of urban and community water and sanitation services in the developing countries, administrative reform especially in the public sector, public policy making and analysis, human resource management and development, international relations, conflict resolution and peace studies, and land policy and administration. 
implementation, and evaluation). The rise in citizen activism in local government activities has placed considerable pressure on local people to demand greater accountability from service bureaucracies in local government system, since the system is more open, accessible, and responsive to its citizens (Alderman, 2012; Schlachter, Coleman, \& Anway, 2013; Serdült \& Yanina, 2015). On account of many failures of the centralized administration in Africa between the late 1980s and the early part of the 1990s, many African countries adopted the local government system of administration (Olowu, 1999). Many of these countries hoped that local government system would help to find meaning for their socio-economic and political existence at the local level (Aina, 2006; Olowu, 1999).

Local government system in Ghana, especially District Assemblies (DAs), has been part of the country's way of life, its heritage and culture. The history of local government is traceable to the colonial period, where chiefs and traditional authorities held military, political, and social power to administer the local affairs (Ahwoi, 2000). The current local government system in Ghana began following the promulgation of the Provincial National Defence Council (PNDC) Law 207 of 1988 (Ahwoi, 2000). The erstwhile PNDC government increased the number of the DAs from 65 to 110. However, after Ghana had returned to the constitutional rule in 1992, the PNDC Law 207 of 1988 was succeeded by chapter 20 of the Constitution and replaced by the local government Act 462 of 1993. Presently, the total number of DAs stands at 216 (Ministry of Local Government and Rural Development in Ghana, 2014). The increase in the size of the DAs reflected the government's intention to deepen democracy, and improve service delivery to promote local level development (Ahwoi, 2010). In Ghana, local government has responsibilities to provide a range of social services such as water, sewers, solid waste collection and disposal, local streets and roads, street lighting, fire and police protection, healthcare, and education (Ofei-Aboagye, 2009). However, little progress has been achieved since the local government reform was launched about two and half decades ago due to a number of internal and external challenges bedevilling the system (Ofei-Aboagye, 2009). The Mfantseman Municipal Assembly, one of the local government institutions in Ghana, suffers similar challenges. These challenges have hindered the Municipality's viability to provide basic public goods and services to promote local development. The Municipality has therefore become an appendage to the central government for support to carry out its responsibilities to reassert its legitimacy and authority. This paper draws on the above to examine the effects of governance challenges facing the Mfantseman Municipality of Ghana. In light of the above, the paper is organized into four sections. Section one provides an introduction; section two presents existing discourse through literature review. Section three describes the research methodology, and section four presents the findings and discussions; the last two sections present the conclusions and recommendations.

\section{Literature Review}

\section{Democratic-Participatory Theory}

Democratic-Participatory Theory has been one of the early theories in Social Sciences, particularly in political science discourse. The discussion on the Democratic-Participatory Theory has been centred on works of Partridge (1963) and Mills (1963). The Democratic-Participatory Theory is based on the premise that local government is the foundation of democratic participation regardless of other intrinsic functions it performs in the state. Broadly, the thesis of the Democratic-Participatory Theory is that local government institutions are created purposely to promote the broad participation of constituents in the direction and operation of political systems. This means that, local government institutions are established to serve as training ground for the 
recruitment of leaders who will make meaningful contributions to decision-making. The institution also seeks to provide direct political education to people at the local levels of the state.

Democratic-Participatory Theory analysts argue that local government is intricately connected to a philosophical commitment which focuses on democratic participation in politics and self-governance at the grassroot levels (Mills, 1963). Since local government officials are closed to the public physically, socially, and psychologically, it encourages democratic participation which promotes accountability of the public administration. It also protects a region or locality from the whims of national government. In addition, participatory democracy helps to enhance the legitimacy of the government by providing a range of services, and also creating a sense of belonging for various social groups within the state (Chukwuemeka, Ugwuanyi, Ndubuisi-Okolo, \& Onuoha, 2014). A broad array of Democratic-Participatory Theorists including Alderman (2012) have also argued that local participation in the local government programmes does not only facilitate poverty alleviation in its local area of jurisdictions, but it also helps the integration of local politicians into national politics.

A critical analysis of the work of Partridge (1963) revealed one important aspect of the Democratic-Participatory Theory. He reveals that the local government primarily serves as a centerpiece that provides the opportunities for the local people to equip themselves with the political knowledge to carry out the decisions for their personal political developments. This means that local government is created to help the assimilation of local-level politicians into the national politics. Tony (2011) has supported the position of the Democratic-Participatory Theorists. He argues that the role of local government is critical in the promotion of democracy, because local government serves as a training ground for democracy, consequently, it helps to ease the frustration that people go through in developing political careers into the national politics. To illustrate this argument, Tony (2011) revealed that in Nigeria, many of the politicians - including Shehu Sagari, Umar Dikko, and Ali Mongumu — started their political careers at the local government level.

In spite of the above claims, Democratic-Participatory Theory has been criticized by a second school of thought led by Fischer (1993). According to him, local government in developed countries can conveniently be described as a foundation of democratic participation but in the African context, the arguments made by the preceding scholars to support the claim that participatory democracy offers opportunities for more involvement of citizens to participate in decision-making and development programmes at the local level are overstated. In explaining his point, Fischer (1993) argued that, in many African countries, the dynamics surrounding the African political systems do not provide the enabling conditions for local government to serve as a training ground for local-level politicians' preparation and further movement into national politics. These dynamics include the domination of political leadership in decision-making at the local government units, absence of set periods for citizens to participate in local government programmes, the nature of the economy, lack of adequate knowledge to contribute to policy making process at the local government units, and the elite capture of local programmes for their personal interest. In addition, in many African countries, the Municipal Councillors (Municipal Chief Executives-MCE) are appointed by central governments. On occasions where the positions are elective, the government in power ensures that it has significant representation on each council. In his view, although local government is regarded as an important agent of political developments, it has not been fully realized in many African states (Fischer, 1993).

A number of recent scholars including Olowu (1999) also argue that in the developing countries, local government system does not open up a number of political opportunities and experiences for citizens, hence, 
service in local government does not automatically create better politicians. According to Olowu (1999), although in the developing countries a number of people work in various capacities in the local government institutions before they move into the national levels, this experience does not necessarily allow them to perform more successfully at their new assignments at the national level. In addition, local government establishments in many developing countries have generally been just corrupt as national government, so young politicians from the local politics enter the national politics with the intention of getting riches quickly. These pertinent submissions made by Olowu (1999) actually reflect the Weberian argument that the closeness of the local bureaucracy to the people really compromises the usefulness of local government, since local officials face enormous problems in being objective and rational (Cigler, 1993; 1998). This is the reality of the African perspective of both the local and national politics. This theory is significantly helpful to provide an insight into the extent of the level of participation of people in local political processes, and why the local government has failed to justify its existence as an agent of democratic participation at the local levels of the state.

\section{Local Government as Agents of Local Development: Emerging Issues and Challenges}

Local government plays an integral part in development in both developed and developing countries (Akhakpe, 2012; Amaechi, 2012). According to the Akhakpe (2012) and Amaechi (2012), local government has been created to bring about development in rural areas. As agents of rural development, local government helps to improve planning and implementation of national development programmes at the local levels. Local government also helps to promote greater flexibility in the implementation of local programmes and provide a means of co-ordinating the various agencies involved at the local levels in the process of development.

Along the same line of reasoning, Wunsch (1991) argued that local government offers opportunities to help neutralize some of the commonly accepted problems of centralized hierarchical and bureaucratic structures. Emphasizing his point further, Wunsch (1991) argued that local government system focuses on the totality of structures within the local community that comprises both state and society organizations to implement local development programmes. Citing examples from France and Belgium to support his view, he maintains that, the system has helped to promote competition, accountability, and cooperation at the local levels, and consequently, helped the utilization of communal norms to promote local development.

Briggs (2007) also provided similar argument to support the viewpoints of the preceding scholars. According to him, local government enhances the responsiveness of the locally elected or appointed bodies towards local problems, because, local officials are mostly found at the local levels, thus, they are able to respond quickly to problems and pressures from the local people without waiting for the approval of agencies at higher levels. Consequently, local government helps to reduce diseconomies of scale, inefficiencies, and low level of responsiveness inherent in the overcentralization of decision-making in the national capital in terms of the provision of basic public goods and services to improve the welfare of the local people (Briggs, 2007).

In spite of all these rationalizations provided to justify the significance of local government to local development, a broad array of scholars including Prud'homme (1995) and Hyden (2006) have vigorously contested the viewpoints of the preceding scholars. Prud'homme (1995) and Hyden (2006) posited that local government does not have the capacity to deliver new responsibilities including the basic public goods and services delivery to the people. In the viewpoints of Prud'homme (1995) and Hyden (2006), local government institutions in many developing countries do not have access to adequate financial resources and efficient administrative capacity to administer local affairs, hence, many local government institutions depend on the 
central government for personnel and financial assistance to help carry out their development programmes, thus, local government institutions often become mere talking shops. This therefore makes the local government system worthless in the developing countries.

Bardhan (2004), with strong concurrence of a school of thought on the subject, also contended that in reality, local government cannot be linked to a number of positive virtues including efficiency, responsiveness, accountability, and participation, especially in developing countries. The point is that, local government institutions in developing countries are bedevilled with issues of misappropriation of funds and misuse of authority. These problems are exacerbated by lack of local democratic practices due to unequal political participation and competition, absence of information available to citizens, incidence of high level of illiteracy, and absence of the central government's ability to perform regular oversight responsibilities on the work of the local government institutions in the state.

In a related study, Kwon (2002) asserted that the argument that local government systems help to improve efficiency in the provision of basic public goods and services, according to the conventional wisdom, may remain true for developed countries, but this may not exactly be the case in the context of the developing countries, because in many developing countries, the management committees of the local government institutions are selected by the central government. Besides, local government institutions are also often "reoriented and reshaped by the central governments in response to emerging constraints and opportunities in society" (Kwon, 2002). In addition, local government institutions are also consistently facing new challenges in the performance of their roles in society. In view of this, Kwon (2002) doubted if the local government institutions in the developing countries have the capacity to provide basic public goods and services efficiently to the local citizens at the grassroot levels (Kwon, 2002).

\section{Methodology}

\section{Data, Rationale, and Method of Analysis}

The study was philosophically guided by social constructivism. The goal of the research, then, was to rely, as much as possible, on the participants' various perspectives and lived experiences of the situations in which they live and work. Based on the constructivist worldview, the researcher employed the qualitative research approach for the study. The study also employed both the convenience and purposive sampling techniques to select the respondents.

To obtain the sample size for the study, a list of all the seven Zonal Councils in the Mfantseman Municipality such as Saltpond, Mankessim, Dominase, Nsanfo, Anomabo, Yamoransa, and Abandze, were identified, and out of the number, four Zonal Councils were selected from the Mfantseman Municipality using the convenience sampling technique. The convenience sampling technique was used because it is the least time consuming technique among all the sampling techniques. Afterwards, a purposive sampling technique was also used to purposefully select 10 local residents from each of the selected Zonal Councils in the Mfantseman Municipality. In all, there were 40 local residents who were selected as respondents from the four Zonal Councils for the study. In addition, a purposive sampling approach was also used to select 10 administrative staff and 10 municipal assembly members from the Mfantseman Municipal Assembly for the study. The purposive sampling technique was used because information sought could only be provided by identified categories of people in the Mfantseman Municipal Assembly. Altogether, there were 60 respondents selected for the study. 
Reconnaissance visit was made from December 15 to December 20, 2015. But the actual fieldwork for the data collection began from January 1, 2016 to January 30, 2016, which was exactly one month. The reconnaissance visit was made in order to develop the trust of the respondents. This helped to provide the opportunity for gaining detailed data from the respondents for the study. The two-phase approach was used to collect data for the study. The first phase, which involved the collection of data from the community people, began on January 1, 2016 and ended on January 15, 2016. The second phase, which involved the collection of data from the administrative staff of the Mfantseman Municipal Assembly and the assembly members, started on January 16, 2016 and ended on January 30, 2016. The primary data were collected through in-depth interviews and focus group discussions. In-depth interviews were informal and conversational in nature, which made it possible for the researcher to probe further when a respondent's response to a question necessitated follow-up questioning. Focus group discussion was also used to generate data for the study. In all, five focus group discussions were held. Each focus group was made up of four men and three women (local residents). Issues that engaged the researcher's attention were challenges facing the municipal assembly, and the measures to resolve them. The rationale for considering multiple data collection instruments was to obtain varied and detailed data to provide an in-depth understanding of the research problem (Stake, 2006). Secondary sources of data for the study were also obtained from articles, the internet, and published and unpublished theses.

The analysis was done manually and followed a number of steps. In the first place, the raw data were reviewed thoroughly to classify initial themes and concepts that emerged from the data obtained from the field. The next step was to build a thematic framework which consisted of themes and sub-themes after identifying general patterns of the data at the first stage. In the third stage, the themes that were identified were indexed by assigning same numbers to themes that had related interpretations which allowed for proper categorization of thematic areas. This step was followed by a descriptive analysis of the themes where elements were properly defined by inspecting each column of the thematic areas. The final step involved a discussion of the findings of the study in the context of existing literature and the theory.

\section{Study Setting}

Mfantseman Municipal Assembly is one of the local government institutions in Ghana, a West African country. Ghana lies between latitudes $5^{\circ} 36^{\prime}$ north and longitudes $0^{\circ} 10^{\prime}$ east. From the coast, the country extends inland to latitude $11^{\circ}$ north, covering a distance of 672 kilometres from south to north. It has a total land area of 239,460 square kilometres. The distance across the widest part from east to west measures about 536 kilometres. To the east of Ghana lies Togo, to the west is La Cote D'lvoire, and to the north is the Republic of Burkina Faso. Ghana's population was estimated to be 25,824,920, with the growth rate of $2.4 \%$ as of 2012 (Ghana Statistical Service, 2012). Mfantseman Municipal Assembly, which serves as the basic unit of governmental administration, is one of the 17 districts in the Central Region of Ghana. The Municipal Assembly's capital town is Saltpond. Mfantseman District Assembly was established through Legislative Instrument (LI) 1574 of 1988. The District was elevated to municipality status by LI 1862 of 2007, after Ekumfi District had been carved out of the District (Ghana Statistical Service, 2012). Mfantseman Municipality is located along the Atlantic coastline of the Central Region of Ghana and extends from latitudes $5^{\circ}$ to $5^{\circ} 20^{\prime}$ north of the equator and longitudes $0^{\circ} 44^{\prime}$ to $1^{\circ} 11^{\prime}$ 'west of the Greenwich Meridian, stretching for about 21 kilometers along the coastline and for about 13 kilometers inland and constituting an area of 612 square kilometers. Mfantseman Municipality is bordered to the West and Northwest by Abura-Asebu-Kwamankese 
District, to the East by Ekumfi District, and to the South by the Atlantic Ocean. Mfantseman Municipality has a total population of 196,563 , which is $9.6 \%$ of the total population of the Central Region (Ghana Statistical Service, 2012).

Farming and fishing constitute the main economic activities in the Municipality, employing about three-quarters of the total workforce. Farming is done in mostly all parts of the Municipality, especially in the inland areas. Foodstuffs and raw materials are usually locked up in the hinterland because most of the feeder roads, especially those linking Mankessim and Saltpond and the coastal communities, are rendered unmotorable during the rainy season. Even where there is access road, the cost of transporting foodstuffs to the urban centres is very prohibitive (Office of the Mfantseman Municipal Assembly, 2014). On water supply, many of the communities in the Municipality are connected to a pipe-borne water system from Bremsu Water Works in Cape Coast. But, frequent power outages coupled with low capacity performance of the system render irregular supply of water (Office of the Mfantseman Municipal Assembly, 2014).

As regards health, there are a number of healthcare institutions in Mfantseman Municipality. However, the attitude of the community people towards accessing healthcare is not encouraging in the Municipality. This stems from the fact that, majority of the residents do not have the financial resources to pay for the quality healthcare services due to the level of poverty in the area, and the somewhat affordable National Health Insurance which could curb the challenge does not cover all healthcare expenses. This is quite surprising because health is seen as an end, and also as a catalyst in the process of development. Better health and nutrition raise productivity, and thus, decrease the number of days workers fall ill and prolong their potential working lives (van der Gaag, 1995).

On the educational front, the Mfantseman Municipality has several educational institutions at various tiers, ranging from day nurseries to senior high schools, technical and vocational schools. All the second cycle institutions are publicly owned (Office of the Mfantseman Municipal Assembly, 2014). It is worthwhile to note that, although the Mfantseman Municipality attaches great value to education, schools located in the communities in the hinterland within the Mfantseman Municipality face staffing problem. The reason is that, majority of the teachers who are posted to schools in the communities in the hinterland sometimes refuse postings because of poor access to basic public goods and infrastructural services such as communication network systems, healthcare, electricity, and housing facilities (Office of the Mfantseman Municipal Assembly, 2014).

\section{Findings and Discussions}

\section{Ineffective Level of Accountability and Coordination}

Effective accountability and coordination are very vital in any local government programme. Accountability and coordination promote efficiency of line agencies and departments of the local government units. Interview with the respondents revealed that the institutional arrangements in the Municipal Assembly did not help to promote the effective level of accountability and coordination of the line agencies, and also Municipal Assembly members and the departments. It was found from the study that the Municipal Assembly had no authority over central government line departments. The deconcentrated sector ministries which provided services within the Municipal Assembly were directly accountable upwards to their parent ministries. Consequently, they remain largely answerable to their ministerial chain of command. This practice has not helped the administrative staff and assembly members to perform their roles successfully in the assembly. As 
part of the discussions, the issue was probed further during the focus group discussions. One of the respondents remarked:

The Municipal Assembly experiences sharp ideological division between the Municipal Assembly members and administrative staff. Within the Municipal Assembly, multiplicities of different political ideologies prevail. This constitutes an obstacle to the effective development planning and coordination in the Municipal Assembly. (Fieldwork, 2016)

The findings from the study show that, the capacity of the Mfantseman Municipal Assembly as a centerpiece to promote socio-economic development is low, due to the ineffective coordination, integrated planning and management at the municipal level. This is caused by a multiplicity of various political ideologies which operate in the municipal assembly. According to the findings, the MCE was appointed by the President; consequently, he is the "handmaid" of the President and not the choice of the population. As a political appointee, he focuses mostly on strengthening the ruling party's structures at the district level, rather than coordinating socio-economic development programmes.

Paradoxically, it was also found that the relationship between the development committee and the communities was not well defined, thus, the residents were denied an effective voice. This situation had made the municipal assembly become a cesspool to political and administrative corruption, primarily, because there were no direct accountability checks on the MCE and the various committees in the Assembly. For example, assembly members did not perform their roles such as organization of meeting to solicit the community's views on policies before going for the assembly meetings. They did not also meet the community people in order to discuss with them the resolutions taken at the municipal assembly session. The weaknesses in intergovernmental relations, and poor coordination among the departments and units tended to create a number of challenges for the municipal assembly. The study also found that basic public goods and services delivery at the district level was aligned with national government plans, instead of a "bottom-up" participatory process. This means that development projects were only approved when they fitted into central government's plans and vision. Thus, planning still tended to be top-down approach. The findings are inconsistent with Mills' (1963) work. According to Mills (1963), local governments help to enhance the legitimacy of the government by providing a range of services, as well as by creating a sense of belonging for various social groups within the state.

\section{Poor Management Capacity}

Efficient local government staff with requisite technical and managerial skills is critical for the delivery of the gains of local governance to the people. Efficiency of the administrative staff is measured by the analytical skills he/she employs in implementing policies to promote success. This is especially so in situations with limited resources including finance. However, in Ghana, there are inadequate human capacities to manage the multiplicity of responsibilities of the local government institutions. This challenge is exacerbated by the exodus of experienced local government staff to take employment in other well-paid institutions, and also appointments of the local government staff based on political patronage rather than the personnel's technical and management skills. Data from the Personnel Records Section of the Mfantseman Municipal Assembly revealed that the Assembly was handicapped in its administrative capacity. The findings showed that majority of the administrative staff did not have the requisite technical and managerial skills. The Finance Section of the Municipal Assembly lacked personnel with technical know-how to handle the finances of the municipality. 
Although, the Finance Sections had been given some in-service training, the weak educational background in financial management is, however, noted to be a challenge facing the proper mobilization and management of resources leading to financial misuse and widespread misappropriation of funds. Consequently, the Municipal Assembly has not been able to provide more social infrastructural services to enhance development of employment opportunities to the teeming unemployed youth. The absence of viable enjoyable economic activities has made the situation quite alarming for many of the young people in the Municipality to migrate to urban towns in search of white-collar jobs, leaving the informal economic activities including farming and fishing to the aged in the municipality. The situation has led to low agricultural productivity, which is the mainstay of the people of Mfantseman Municipality. In addition, many respondents attributed the widespread social vices in urban towns in the municipality including Mankessim, Saltpond, Anomabo, and Yamoransa, to the rural folks, who return from the cities after failing to make decent living in the cities. These findings do not tally with the works of Cigler (1993; 1998). According to Cigler (1993; 1998), local government provides opportunity for the enhancement of local economic development to help improve the welfare of the local people.

\section{Inadequate Financial Resources}

Inadequate financial resources were also found to be one of the challenges bedevilling the Municipality's socio-economic development. Discussions with the administrative staff revealed that the central government funding, the District Assemblies Common Fund (DACF) was the major source of revenue of the Municipality. Thus, the Municipality is not fiscally autonomous since it has weak institutional and administrative capacities in mobilizing enough internally generated revenue. Findings from the Municipality revealed that, the Assembly's internally generated revenue in 2015 amounted to GHC 903,836.91 (US\$258,239.12; exchange rate GHC 3.5: US\$1). The main sources were rates: GHC 250,000.0 (US\$71,428.57), fees and user charges: GHC 404,081.81 (US\$115,451.95), fines: GHC 4,500.00 (US\$142.86), licenses: GHC 156,245.12 (US\$44,641.57), land: GHC 43,584.51 (US\$12,452.72), and rent: GHC 20,425.47 (US\$5,835.85). Other income derived from investment interest, dividend interest, income from public enterprise, and fines were GHC 25,000.0 (US\$7,142.86), and the DACF was GHC 3,289,757.86 (US\$939,930.82). From the annual progress report of the Municipal Assembly, it was found that, not much was achieved by the Assembly in the area of internal revenue mobilization, because the taxing powers of the Assembly were not extensive enough. Consequently, the yield from existing sources was not sufficient to meet both socio-economic developments and recurrent services. There are a number of issues bedevilling the financial crisis in the Mfantseman Municipal Assembly. The first is the outmoded nature of the system used to collect the property rates and service charges from the local people. Secondly, the revenue collectors and their supervisors have often diverted revenues collected into their personal pockets. Thirdly, Mfantseman Municipal Assembly continues to face the problem of "culture of non-payment" of charges for basic public goods and services, largely by urban dwellers. In addition, it was revealed that there was no transparency and openness in how the DACF was utilized to finance development projects in the communities. The issue was probed further during the focus group discussion. One of the respondents highlighted:

There is a complete lack of transparency and openness in terms of utilization of DACF to finance development projects in the communities in the Municipality. Actually, good governance practices such as transparency, openness and access to information are not observed by the Municipal Assembly. This has endangered the successful utilization of the DACF to finance socio-economic development programmes in the communities. (Fieldwork, 2016) 
The preceding findings have shown that the DACF which serves as the major source of revenue for development programmes was not only insufficient, but also the community people did not have the opportunity to give their inputs regarding the utilization of the DACF towards financing projects in the communities, due to the insufficient access to information from their representatives (Assembly Members), openness and transparency of procedures surrounding the management of the DACF. From the diagnosis, it is clear to note that there is a high degree of external influence and interference in local government affairs, which tends to undermine the Municipality's developmental capacity. The findings corroborate a similar study by Prud'homme (1995) and Hyden (2006) that in developing countries, local government has weak administrative capacity to manage their own fiscal decisions, as well as an independent decision-making capacity in determining the quantity and quality of socio-economic development programmes.

\section{Low Level of Local Participation}

Direct citizen participation in local government programmes helps to shape decisions that affect them. Participation by both men and women is also central to good governance. In reality, the very essence of local government since colonial times is the urge to make governance local, that is, as close to the people as possible (Olowu, 1999). In addition, Ghana's Constitution underscores the importance of the participation of the local people. Article 240, Section 2e states that "to ensure the accountability of local government authorities, people in particular local government areas shall, as far as practicable, be afforded the opportunity to participate effectively in their governance" (Republic of Ghana, 1993). Besides, participation also tends to encourage the community to identify and meet their basic needs. Interviews with the respondents during the fieldwork revealed that the local people were not provided much opportunity to participate in deliberations on important issues that affect them in the communities within the municipality. For example, where the opportunity was given to participate in the discussion of issues that affect them, their contributions during the forum were ignored by the municipal officers, because they were considered illiterates. In view of this, the willingness of the community people towards maintenance of the community projects was not encouraging at all. Thus, some of the communities always expect the Government of Ghana and the Municipal Assembly to come to their aid in maintaining projects for them in the event of breakdown. This is surprising because DAs in Ghana are ideally placed as the locus of direct citizens' involvement due to its existing community ties and closeness to the people. The findings are consistent with Fischer's (1993) work which notes that in African states, the domination of political leadership in decision-making at the local government units does not allow the local government to serve as an avenue for local level participation at the grassroot levels of the state.

\section{Conclusions}

Various governments in Ghana since independence have appreciated the importance of an effective local government system. They duly recognize that an effective local government system promotes development at the grassroot levels. However, the DAs', especially the Mfantseman Municipal Assembly's capacity to fulfill these responsibilities and expectations has not grown to meet the expectations of the people. Significant challenges responsible for this state of condition included the ineffective level of accountability and coordination, poor management capacity, inadequate financial resources, and low level of local participation. Thus, the Mfantseman Municipal Assembly has become more than an appendage of the status quo centralized system. This is because while the Mfantseman Municipal Assembly's responsibilities are expanding, the 
sources of revenue and the institutional system to carry out the social and economic services continue to remain unreliable and non-existent. In view of this, the Municipal Assembly is highly handicapped in taking up its own cause and initiating change towards the promotion of socio-economic development programmes, but rather continues to depend hugely on the central government for financial assistance to initiate local level development programmes. Following the above, it is important that the Mfantseman Municipal Assembly takes a more effective approach to building effective institutional system which involves group-negotiated decisions, especially with citizens, private and non-profit organizations, and administrative staff who can work together closely with the local citizens to synchronize state and societal resources for local development.

\section{Recommendations}

This paper has provided an insight into the governance challenges facing the Mfantseman Municipal Assembly of Ghana. Following this, a number of measures are proposed to resolve the challenges facing the performance of the Mfantseman Municipal Assembly of Ghana.

Firstly, the Mfantseman Municipal Assembly must endeavour to improve its performance in internally generated revenue through the involvement of the private sector and special revenue task forces in mobilizing revenue from all possible sources to supplement the DACF, which is provided to the Assembly by the central government. This is imperative since the DACF received from the central government transfer alone is not adequate in meeting the needs and requirements of development expenditure of the Municipality.

Secondly, the rigid control of the fund by various governmental agencies such as Parliament, the Ministries of Finance, Local Government and Rural Development, the District Assemblies Common Fund Administrator, and the Accountant General Department poses a hindrance to the Municipal Assembly's fiscal autonomy. In view of this, it is suggested that, these institutions are made flexible so that the Municipal Assembly would gain fiscal autonomy to utilize the resources according to the Assembly's own sense of priorities to promote local level development.

Thirdly, the levels of accountability and coordination in the Municipal Assembly are generally weak. This, therefore, has affected the efficiency of line agencies and various departments in the Municipal Assembly. To address this challenge, the Assembly should ensure that regular consultation is done with all identifiable groups including the administrative staff, assembly members, the traditional authorities, women groups, local people, civil society organizations, and opinion leaders in the Municipality. This would help to improve compliance with policy goals of the Assembly, and thus, help restrain uncoordinated fiscal policies and avoid planning and expenditure overlaps that create opportunities for misappropriation of funds, and ineffective accountability of line agencies and various departments in the Assembly.

Fourthly, the Mfantseman Municipal Assembly should endeavour to encourage the participation of the local people in their development programmes. This would enable the community people to feel empowered, and consequently, render their cooperation towards development activities in the Municipality. Finally, in the area of personnel management challenges, training courses in budgeting and other subjects of prime importance should be part of the capacity building programmes of the Assembly. More importantly, there is the need to move away from the notions of classical theoretical education which dominated some past training efforts. More active formats emphasizing problem-solving and proper management finances are needed. This is likely to help the Assembly to perform its roles and responsibilities effectively to improve the welfare of the people in its areas of jurisdiction. 


\section{References}

Ahwoi, K. (2000). Trends in local government reforms and decentralization in Ghana. In W. Thomi, P. W. K. Yankson, and S. Y. Zanu (Eds.), A decade of decentralization in Ghana: Retrospect and prospects. Accra: Gold Tyre Ltd.

Ahwoi, K. (2010). Local government and decentralization in Ghana. Accra, Ghana: Macmillan Publishers Ltd.

Aina, D. A. (2006). State and local government in Nigeria: The changing scene. In O. Aborissade and I. O. Aransi (Eds.), From native administration, divisional administration to council managership and local government (pp. 279-303). North Carolina: Catawba.

Akhakpe, I. (2012). Public administration: Qualities, functions and constraints of public administrators. In I. Olojide and S. Fajonyomi (Eds.), Essentials of public administration. Lagos: Sage Prints.

Alderman, G. (2012). Local government system: A comparative perspective. Retrieved from http://www.cenresinpub.org/pub/ Dec2012/JSSPR/Page\% 252043-671054

Amaechi, R. (2012). The debate on local government autonomy. Retrieved from http://www.thisdaylive.com/article/the-debate-on -local-government-autonomy

Bardhan, P. (2004). Decentralization of governance and development. Berkeley: Department of Economics, University California.

Briggs, B. (2007). Participation in self-help projects among rural inhabitants: A comparison. Quarterly Journal of Administration, 11(4), 285-296.

Chukwuemeka, E., Ugwuanyi, B. I., Ndubuisi-Okolo, P., \& Onuoha, C. E. (2014). Nigeria local government: A discourse on the theoretical imperatives in a governmental system. An International Multidisciplinary Journal, Ethiopia, 8(2), 305-324.

Cigler, B. A. (1993). State-Local relations: A need for reinvention? Intergovernmental perspective. Boulder, CO: Westview Press.

Cigler, B. A. (1998). Emerging trends in state-local relation. In R. L. Hensen (Ed.), Governing partners: State-Local relations in the United States (pp. 53-74). Boulder, CO: Westview Press.

De Mello, L., \& Lago-Peñas, S. (2012). Local government cooperation for joint provision: The experiences of Brazil and Spain with inter-municipal consortia. Working paper 12-18. International Center for Public Policy, Georgia State University.

Fischer, F. (1993). Citizen participation and the democratization of policy expertise: From theoretical inquiry to practical cases. Policy Sciences, 26, 165-187.

Ghana Statistical Service. (2012). Ghana population and housing census 2010. Accra, Ghana.

Hyden, G. (2006). African politics in comparative perspective. Cambridge, MA: Cambridge University Press.

Kwon, S. (2002). The effects of fiscal decentralization on public spending: The Korea case. Proceedings from 13th Annual Conference on Public Budgeting and Financial Management. Washington, D.C.

Mills, C. W. (1963). The unity of work and leisure. In I. L. Horowitz (Ed.), Power, politics and people. New York: Oxford University Press.

Ministry of Local Government and Rural Development in Ghana. (2014). Report on the local government systems. Accra, Ghana.

Ofei-Aboagye, E. (2009). Economic decentralization and local development: Concepts and issues. Journal of Local Government Studies, 1(1), 3-28. Institute of Local Government Studies, Accra.

Office of the Mfantseman Municipal Assembly. (2014). Medium term report. Saltpond, Mfantseman, Central Region of Ghana.

Olowu, D. (1999). Local governance, democracy, and development. In R. Joseph (Ed.), State, conflict, and democracy in Africa. Boulder: Lynne Rienner.

Partridge, P. H. (1963). Some notes on the concept of power. Political Science Quarterly, 61, 573-588.

Prud'homme, R. (1995). On the dangers of decentralization. Policy working paper 1252. Washington, D.C.: World Bank.

Republic of Ghana. (1993). The district assemblies common fund act (act 455). Tema: Ghana Publishing Corporation.

Schlachter, B., Coleman, M., \& Anway, H. (2013). Fiscal policy and governance committee key challenges and strategies for local government. University of Pittsburgh Institute of Politics. Retrieved from http://Challenges\%20and\%20Strategies/ 20 for $\% 20$ Local $\%$

Serdült, U., \& Yanina, W. (2015). How sustainable is democratic innovation? Tracking neighborhood councils in Montevideo. Journal of Politics in Latin America, 2, 131-148.

Stake, R. E. (2006). Multiple case study analysis research methods. New York: Guilford Press.

Tony, O. (2011). Key issues in local government and development: A Nigerian perspective. Enugu: Praise House Publishers.

van der Gaag, J. (1995). Private and public initiatives: Working together for health and education. Direction in Development Serves. Washington, D.C.: The World Bank.

Wunsch, J. (1991). Institutional analysis and decentralization: Developing an analytical framework for effective third world administrative reform. Public Administration and Development, 11(5), 431-451. 